\title{
Matt Morgan: We should encourage short service awards
}

\author{
Matt Morgan intensive care consultant \\ University Hospital of Wales
}

As I walk towards the sound of 1970 s music, coloured disco lights spill out from the window. I clutch a quickly wrapped bottle of cold wine, snatched from the fridge as I left the house. But an early start the next day means that the only drinks I'll be having tonight will contain caffeine rather than the alcohol that sustains the bad dancing.

As I enter the social club, a line of hungry people talk about the weather, football, and Brexit while balancing beige, pastry based snacks on unstable cardboard plates. A silver banner, too small for the huge white wall it's stuck on, exclaims the reason for tonight's celebrations: "HAPPY RETIREMENT!"

For the doctor retiring, it's been 30 years of sick patients, grateful families, and endless mandatory training-interspersed with times that made you smile, times that made you cry, times that you will remember forever, and times that you would rather forget.

The hospital's medical director shuffles on to the dance floor, tapping the microphone to try to be heard above the sounds of "Dancing Queen." The speech contains all of the right words: commitment, treasure, grateful, missed, dedication, thanks. The big moment arrives when an oversized card, signed by hundreds of people, is carried in from the sidelines, and they present you with that special gift that will soon feature on your mantelpiece. You deserve it, and we all applaud loudly.

\section{Other people, other places}

While the private sector embraces frequent moves, job shuffles, and the multi-hyphen method of people's portfolio careers, healthcare still celebrates staff who show dedication, through long service awards. But, although this is only right and proper, we should celebrate short service too.

By reducing the number of geographical rotations that doctors experience to just a small cluster of hospitals—and by implementing more prescriptive, inflexible local guidelines, which are often based on politics as much as their worth-we risk losing the learning and experience that come from working with other people, in other places. "This is how we do it here" is fine, as long as you also experience "how they do it there." Run-through training schemes, based around a small number of hospitals - in one country, one county, even one city-can put the breadth of medicine at risk. A narrow focus can be powerful in healthcare, as long as you gaze at the horizon now and then. To help doctors obtain such long-sightedness, the process of moving between hospitals and experiencing different environments should be easy, seamless, and even encouraged.

So, perhaps we need short service awards as well as long service ones.

Competing interests: I have read and understood BMJ policy on declaration of interests and declare that I have no competing interests.

Provenance and peer review: Commissioned; not externally peer reviewed.

Matt Morgan is an honorary senior research fellow at Cardiff University, consultant in intensive care medicine and research and development lead in critical care at University Hospital of Wales, and an editor of BMJ OnExamination.

Published by the BMJ Publishing Group Limited. For permission to use (where not already granted under a licence) please go to http://group.bmj.com/group/rights-licensing/ permissions 